\title{
Sex sorting sperm of sumba ongole bulls by using snakehead fish (Channa striata) albumin extract
}

\author{
T. Maulana ${ }^{1,3}$, S. Said ${ }^{3}$, R.I. Arifiantini' ${ }^{2}$ and M.A. Setiadi ${ }^{2}$,* \\ ${ }^{1}$ Reproductive Biology Study Program, Graduate School of IPB University, \\ Dramaga Campus, Bogor 16680 - Indonesia \\ ${ }^{2}$ Division of Reproduction and Obstetric, Department of Veterinary Clinic Reproduction and Pathology, \\ Faculty of Veterinary Medicine, IPB University, \\ Jl. Agatis, Dramaga Campus, Bogor 16680 - Indonesia \\ ${ }^{3}$ Laboratory of Reproduction, Genetics and Animal Cell Culture, \\ Research Center for Biotechnology, Indonesian Institute of Science (LIPI) \\ Jl. Raya Bogor km.46, Cibinong Bogor 16914.- Indonesia \\ *CorrespondingE-mail: setiadi03@yahoo.com
}

Received October 12, 2018; Accepted February 19, 2019

\begin{abstract}
ABSTRAK
Penelitian ini bertujuan untuk mengetahui efektifitas ekstrak albumin ikan gabus (Channa striata) terhadap karakteristik dan proporsi spermatozoa X dan Y Sumba Ongole setelah pemisahan menggunakan metode kolom channalbumin. Semen dikoleksi dari tiga sapi SO menggunakan vagina buatan kemudian dievaluasi secara makroskopis dan mikroskopis. Albumin ikan gabus (channalbumin) diekstrak dari ikan gabus. Kolom channalbumin dibuat dalam konsentrasi yang berbeda pada fraksi atas dan bawah: 2\%:4\%; 3\%:5\%; 4\%:6\% dan kontrol BSA 5\%:10\%. Semen kemudian ditransfer pada fraksi atas kemudian diinkubasi selama 30 menit pada suhu ruang kemudian setiap fraksi dikoleksi dan disentrifugasi pada kecepatan $1800 \mathrm{rpm}$ selama 10 menit. Supernatan kemudian dibuang dan pellet dievaluasi karakteristiknya meliputi; motilitas, abnormalitas, viabilitas dan integritas membrane serta morfometrik kepala spermatozoa. Hasil menunjukkan channalbumin mampu mepertahankan motilitas spermatozoa pada fraksi atas dibandingkan fraksi bawah. Viabilitas dan integritas membran spermatozoa kontrol BSA berbeda nyata $\mathrm{P}<0.05$ dibandingkan dengan perlakuan channalbumin. BSA 5\%:10\% lebih tinggi proporsi sperm $\mathrm{X}$ and $\mathrm{Y}(69 \%: 76.77 \%)$ dibandingkan perlakuan channalbumin 2\%:4\% (42.33\%:79.13\%), 3\%:5\% (55.97\%:75.73\%) dan 4\%:6\% (62.77\%:68\%). Kesimpulan, channalbumin (4\%:6\%) efektif untuk pemisahan spermatozoa X dan Y dengan proporsi tertinggi.

Kata kunci: channalbumin, sexing, spermatozoa, snakehead, Sumba Ongole
\end{abstract}

\begin{abstract}
The objective of this research was to investigate the potential of snakehead albumin extract (channalbumin) for sorting $\mathrm{X}$ and $\mathrm{Y}$ sperm of Sumba Ongole (SO) and its characteristic. Semen was collected from three SO bulls using artificial vagina and the freeze dried channalbumin was extracted from snakehead fish. Channalbumin column was made with different concentration ratio of top and bottom fraction: $2 \%: 4 \% ; 3 \%: 5 \% ; 4 \%: 6 \%$ respectively and BSA 5\%:10\% as control. Semen was put in top fraction then incubated for $30 \mathrm{~min}$ at room temperature then each fraction was centrifuged at 1800 rpm for 10 minutes. The pellet was evaluated for motility, abnormality, viability, membrane integrity and
\end{abstract}


head sperm morphometric. The results showed that the channalbumin capable to maintain sperm motility in the top fraction better than the bottom fraction. Sperm viability and membrane integrity in control group were significantly higher $(\mathrm{P}<0.05)$ than all channalbumin treatment. BSA 5\%:10\% has highest proportion of $\mathrm{X}$ and $\mathrm{Y}$ sperm (69\%:76.77\%) compared with $2 \%: 4 \%$ (42.33\%:79.13\%), 3\%:5\% (55.97\%:75.73\%) and 4\%:6\% of channalbumin (62.77\%:68\%). It's concluded that channalbumin 4\%: $6 \%$ was effective for separation of XY sperm with higher proportion.

\section{Keywords: Channalbumin, Sexing, Sperm, Snakehead, Sumba ongole}

\section{INTRODUCTION}

Sumba ongole (SO) a one of the Bos indicus has distinctive physical characteristics compared to other local cattle and adaptable to extreme conditions, high carcass percentage and is potentially excellent utilized as beef cattle (Agung et al., 2015). The application of reproductive biotechnology in the livestock industry is important to increase livestock productivity in order to accelerate the improvement of genetic quality and livestock population.

Sex sorting sperm is a reproductive biotechnology which capable to control sex ratio of calves born for specific purpose by separated sperm bearing $X$ and $Y$ chromosome. Sperm with $\mathrm{X}$ and $\mathrm{Y}$ chromosome have several characteristic differences such as DNA content, morphology, motility, mass weight and specific genes contained therein (Sharma and Sharma, 2016).

Furthermore, there are several separation methods which have been developed include sedimentation, albumin column, centrifugation, percoll density gradient, electrophoresis, filtration with sephadex column, HY antigen, and flowcytometry sorting cell (Sharma and Sharma, 2016). In Indonesia several separation methods have been applied in local and national artificial insemination center such as albumin column method with 5\%:10\% bovine serum albumin (BSA) separation with genital compatibility offspring by artificial insemination more than 85\% (Kaiin et al., 2013; Gunawan et al., 2017) or using an egg white albumin (10\%:30\%) (Afiati, 2004).

However, separation of sperm with albumin columns has several problems, such as decrease of frozen semen quality, high cost and limited availability of separation material. Based on these problems, providing an alternative low cost and reliable local material is required.

Based on molecular weight channalbumin is considered as an alternative material for sperm separation. Nugroho (2013) reported, snakehead albumin have similar molecular weight $66.3 \mathrm{KDa}$ comparable with BSA (66.5 KDa) and human serum albumin (HSA) (67 KDa). Determination of using snakehead albumin based on similiarity material viscosity compared to BSA coloumn method (Kaiin et al., 2013). This study was aimed to investigate the potential of snakehead albumin extract (channalbumin column) for sorting $\mathrm{X}$ and $\mathrm{Y}$ sperm of sumba ongole (SO) and its characteristic.

\section{MATERIALS AND METHODS}

This study was conducted at PT. Karya Anugerah Rumpin (PT. KAR) Bogor and Laboratory of Reproduction, Genetics and Animal Cell Culture, Research Center for Biotechnology, Indonesian Institute of Science, Bogor Indonesia from January-May 2018. A total of three certified SO bulls aged 4-5 years old and live mount teaser were used. The bulls were confined in individual stall barn for 24 hours, except several hours for exercise and the day of semen collection. All bulls were fed according to PT. KAR.

\section{Snake Head Fish Albumin Extraction}

Chanalbumin was extracted from snakehead fish $\pm 250 \mathrm{~g}$ of weigh. According to Romadhoni et al. (2015) and Nugroho (2013) method with slight modification. The meat was sliced into small pieces using transversal cut and the bones were removed. Fillets were cleaned with distilled water and placed in a pre-weighted container. Fresh snakehead extract was processed by steaming with aquadest in 1:1 proportion (100 $\mathrm{g}$ snakehead : $100 \mathrm{~mL} \mathrm{H}_{2} \mathrm{O}$ ) on the hotplate at 50$60^{\circ} \mathrm{C}$ for 10 minutes then the extract were filtered. Protein and lipid of crude extract were separated by $\mathrm{N}-\mathrm{Hexana}$ in 1:1 proportion for 30 minutes at room temperature. Crude extracts were then placed in separation funnel until two layers were formed. Only bottom layer was then collected and centrifuged in $9.000 \mathrm{rpm}$ at $4^{\circ} \mathrm{C}$ for 20 minutes and only supernatant was collected and filtered using $11 \mu \mathrm{m}$ filter (Whatman ${ }^{\circledR}$ filter papers) to obtained channalbumin extract then stored at -80 
${ }^{\circ} \mathrm{C}$ before freeze drying process. Freeze drying was done using freeze dryer (Christ Alpha 1-4 LD plus) $-60^{\circ} \mathrm{C}$ for 48 hours at 0.011 mbar pressure.

\section{Semen Collection and Evaluation}

Semen collection was conducted twice a week using artificial vagina. The collected semen was then immediately brought to the laboratory for initial evaluation. Evaluation of sperm quality was analyzed macros-pically (volume, $\mathrm{pH}$, color and consistency) and microscopically (mass motility, motility, concentration, abnormality, viability and membrane integrity) (IAEA 2005).

\section{Sexing Sperm using Channalbumin Column}

Semen concentration was diluted with final concentration $200 \times 10^{6} \mathrm{sperm} / \mathrm{mL}$ in tris buffer (Tris aminomethane $3.03 \mathrm{~g}$ citric acid $1.78 \mathrm{~g}$, fructose $1.25 \mathrm{~g}$, penicillin streptomycin $100 \mu \mathrm{L}$, $\mathrm{H}_{2} \mathrm{O} 100 \mathrm{~mL}$ ) Aliquot $1 \mathrm{~mL}$ sperm added into sexing tube base on treatment (Figure 1):

$\begin{aligned} \text { P0 } & : \begin{array}{l}\text { Control BSA column } \\ \text { proportion }=5 \%: 10 \%\end{array} & \text { (top:bottom) } \\ \text { P1 } & : \begin{array}{l}\text { Channalbumin column } \\ \text { proportion }=2 \%: 4 \%\end{array} & \text { (top:bottom) } \\ \text { P2 }: & \begin{array}{l}\text { Channalbumin column } \\ \text { proportion }=3 \%: 5 \%\end{array} & \text { (top:bottom) } \\ \text { P3 } & : \begin{array}{l}\text { Channalbumin column } \\ \text { proportion }=4 \%: 6 \%\end{array} & \text { (top:bottom) } \\ & & \end{aligned}$

Semen was incubated for 30 minutes at room temperature of $27^{\circ} \mathrm{C}$. Thereafter, each sperm fraction was collected and transferred using micropipette into $15 \mathrm{~mL}$ centrifuge tube and added with tris buffer. The tube was then centrifuged at $1800 \mathrm{rpm}$ for 10 minutes at room temperature, then pellet was added with $1 \mathrm{~mL}$ Tris buffer. The bottom fraction was predicted as $\mathrm{Y}$ sperm and top fraction as $\mathrm{X}$ sperm (Kaiin et al., 2013). The assessmen of post sexing sperm quality from both fractions was then observed, in term of its motility, viability, abnormality, membrane integrity and morphometric of head sperm.

Sperm Motility. Sperm motility (\%) was assessed subjectively using microscope set at magnification of $200 \mathrm{x}$ and $400 \mathrm{x}$ (IAEA, 2005).

Sperm viability and abnormality. Sperm viability (live or dead sperm) and abnormality (\%) were assessed using microscope set at magnification $200 \mathrm{x}$. Post sexing sperm then mixed with eosin nigrosin staining and smeared on object glass (IAEA, 2005).

Sperm Membrane Integrity. Sperm membrane integrity (\%) was determined by calculation of the percentage of sperm having intact plasma membrane by hypo-osmotic swelling (HOS) test. HOS test was performed by incubating $100 \mu \mathrm{L}$ of sperm sample into $1 \mathrm{~mL}$ of $150 \mathrm{mOsm} / \mathrm{L}$ hypoosmotic solution for 60 minutes at $37^{\circ} \mathrm{C}$. One drop of the mixture was then evaluated under light microscope at 400x. Sperm with intact plasma membrane are indicated with curled or swelled tail, while the defect or dead sperm are marked by a straight tail were observed. A total of 100 sperm were assessed in each replicate (Padrik et al., 2012).

Sperm Head Morphometric. The sperm smear was fixed by fire on the slide glass on a bunsen burner and washed using ethanol absolute for 4 minutes, and the glass was then air-dried. The slide glass was washed in chloramine $0.5 \%$ solution for 2 minutes, then drain with distilled water and washed using 95\% ethanol. The sperm slide glass was then stained by Williams staining for 8-10 minutes and immediately drain with flow water and air-dried (Kavac, 2010). Sperm was evaluated using ImagerZ Carl Zeiss microscope with 400x magnification then analyzed using ImageJ software to measure area, perimeter, length and width of head sperm. Total 1000 sperm were measured in each fraction. Sperm bearing $X$ chromosome have larger size head morphometry than Y sperm.

\section{Statistical Analysis}

All data for quality of freshly ejaculated semen, quality after sex sorting, morphometric sperm and proportion $\mathrm{X}$ and $\mathrm{Y}$ sperm obtained were presented as means \pm standard deviation (SD) and analyzed by one-way analysis of variance (ANOVA) using Minitab 17 for Windows except proportion XY were analyzed with description. Differences between treatments were considered statistically significant at $\mathrm{P}<0.05$ by Fisher LSD analysis.

\section{RESULTS AND DISCUSSION}

\section{Quality assessment of SO bulls fresh semen}

The quality of fresh semen of SO bulls were examined macro- and microscopically as presented in Table 1. According to Axl et al. 
(2000) and IAEA (2005) the semen characteristics of SO bulls used in this study were categorized as still good semen quality with progressive motility $>50 \%$, concentration $>500$ million $/ \mathrm{mL}$ abnormal sperm $<20 \%$. Further research by Kaiin et al. (2013) reported that minimum requirements motility for sex sorting sperm using BSA columns was $60 \%$.

\section{Sperm quality after separation}

The quality of sperm after separation at the top and bottom fractions can be seen in Tables 2 and 3. Table 2 showed the sperm motility on the top fraction was not different between BSA (66.67 $\pm 4.44 \%$ ) compared to $2 \%$ chanalbumin treatment $(65.91 \pm 3.75 \%), 3 \%(64.00 \pm 3.16 \%)$ and $4 \%$ $(63.50 \pm 4.12 \%)$ respectively. Channalbumin treatment could maintain sperm motility after separation comparable with sperm treated by $5 \%$ BSA. In contrary, sperm motility on bottom fraction in BSA $10 \%$ was significantly higher (66 $\pm 2.11 \%$ ) compared to all channalbumin treatment $(4 \%(59 \pm 5.16 \%), 5 \%(54.44 \pm 3.91 \%)$ and $6 \%$ ( $49.44 \pm 5.83 \%)$, respectively.

Our further result on sperm viability both in the top and bottom fractions were higher in the control BSA $5 \%$ and $10 \%$ compared to all channalbumin treatment (Tables 2 and 3). There were no significant differences in the sperm abnormalities after separation both in the top and

Table 1. Fresh Semen Quality of SO Bulls

\begin{tabular}{lc}
\hline \multicolumn{1}{c}{ Parameters } & $\begin{array}{c}\text { Quality } \\
\text { (Mean } \pm \text { SEM) }\end{array}$ \\
\hline Volume (mL) & $6.60 \pm 1.68$ \\
$\mathrm{pH}$ & $6.78 \pm 0.13$ \\
Mass motility & ++ \\
Color & creamy - yellow \\
& creamy \\
Consistency & watery - slightly \\
thick & $1,256.42 \pm 208.34$ \\
Concentration $\left(\mathrm{x} 10^{6} / \mathrm{mL}\right)$ & $62.92 \pm 4.98$ \\
Motility (\%) & $62.73 \pm 6.15$ \\
Viability (\%) & $13.43 \pm 3.43$ \\
Abnormality (\%) & $62.61 \pm 3.97$ \\
Membrane integrity (\%) & \\
\hline++ mass movement motility & of sperm swirling \\
motion &
\end{tabular}

bottom fraction among the control group and all channalbumin treatment (Tables 2 and 3). The sperm membrane integrity of the top and bottom fraction showed, control BSA 5\% and $10 \%$ were higher compared to all channalbumin treatment (Tables 2 and 3).

Sperm motility after separation process especially channalbumin treatment in the bottom fraction showed decreased in motility. This due to energy reduction while incubation for $30-40$ minutes at room temperature until sperm washing also reduces seminal plasma concentration which contributes to disruption of sperm motility. This data supported by Moura et al. (2007) who indicated that seminal plasma have function to maintain sperm viability, protecting sperm membranes and initiating sperm motility. Furthermore Burroughs et al. (2013) reported, removing seminal plasma immediately after sperm collection increased sort rate and number of live sperm after sorting.

The sperm motility in the bottom fraction of all channalbumin treatments $(4 \%, 5 \%$ and $6 \%$ ) was lower than BSA $10 \%$. This is might be caused by channalbumin purity level. Based on our observation microscopically, channalbumin was still contains material in the form gel and particles. Those particles are might be collagen which were derived from bone or skin that was still attached to the meat. This data supported Chasanah et al. (2015) and Mustafa et al. (2012) that snakehead fish has high Lysine amino acid for collagen formation and also high Glycine and Aspartic acid for accelerate wound healing. Lower motility in channalbumin treatment due to low selenium mineral component that could be as an antioxidant.

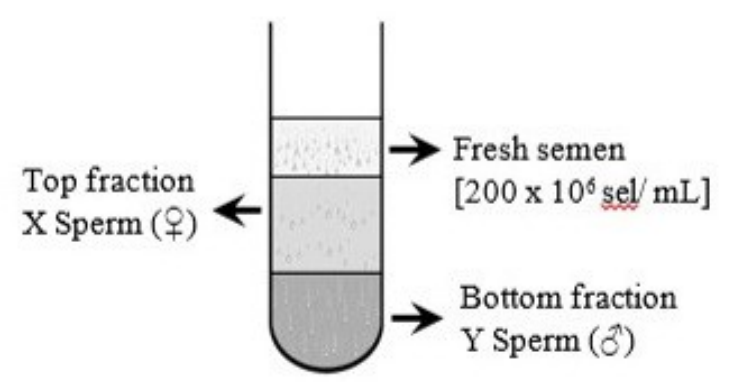

Figure 1. Illustration of sexing sperm using channalbumin column 
Table 2. Sperm Characteristics after Sexing at Top Fraction (X Sperm)

\begin{tabular}{ccccc}
\hline \multirow{2}{*}{ Treatment } & \multicolumn{4}{c}{ Sperm Characteristic (Mean \% \pm SD) } \\
\cline { 2 - 5 } & Motility & Viability & Abnormality & Membrane Integrity \\
\hline P0x & $66.67 \pm 4.44$ & $71.80 \pm 4.79^{\mathrm{a}}$ & $8.08 \pm 2.76$ & $71.58 \pm 7.68^{\mathrm{a}}$ \\
P1x & $65.91 \pm 3.75$ & $66.16 \pm 4.36^{\mathrm{b}}$ & $8.84 \pm 2.82$ & $69.15 \pm 4.70^{\mathrm{ab}}$ \\
P2x & $64.00 \pm 3.16$ & $65.49 \pm 3.91^{\mathrm{b}}$ & $7.86 \pm 2.53$ & $65.33 \pm 6.64^{\mathrm{ab}}$ \\
P3x & $63.50 \pm 4.12$ & $63.58 \pm 5.90^{\mathrm{b}}$ & $8.03 \pm 2.88$ & $63.44 \pm 6.48^{\mathrm{b}}$ \\
\hline
\end{tabular}

$\mathrm{P} 0 \mathrm{x}=$ control of $5 \%$ BSA $(\mathrm{w} / \mathrm{v}), \mathrm{P} 1 \mathrm{x}=2 \%$ channalbumin $(\mathrm{w} / \mathrm{v}), \mathrm{P} 2 \mathrm{x}=3 \%$ channalbumin $(\mathrm{w} / \mathrm{v}), \mathrm{P} 3 \mathrm{x}=4 \%$ channalbumin $(\mathrm{w} / \mathrm{v}) ;{ }^{\mathrm{a}, \mathrm{b}} \mathrm{Mean} \pm \mathrm{SD}$ with different superscript within columns is differ significantly $(\mathrm{P}<0.05)$.

Table 3. Sperm Characteristics after Sexing at Bottom Fraction (Y Sperm)

\begin{tabular}{ccccc}
\hline \multirow{2}{*}{ Treatment* } & \multicolumn{4}{c}{ Sperm characteristic (Mean \% \pm SD) } \\
\cline { 2 - 5 } & Motility & Viability & Abnormality & Membrane integrity \\
\hline P0y & $66.00 \pm 2.11^{\mathrm{a}}$ & $70.47 \pm 4.95^{\mathrm{a}}$ & $7.20 \pm 2.69$ & $70.64 \pm 5.32^{\mathrm{a}}$ \\
P1y & $59.00 \pm 5.16^{\mathrm{b}}$ & $58.32 \pm 6.92^{\mathrm{b}}$ & $7.29 \pm 2.84$ & $56.53 \pm 7.15^{\mathrm{b}}$ \\
P2y & $54.44 \pm 3.91^{\mathrm{b}}$ & $58.79 \pm 5.12^{\mathrm{b}}$ & $6.14 \pm 1.50$ & $53.01 \pm 7.35^{\mathrm{bc}}$ \\
P3y & $49.44 \pm 5.83^{\mathrm{c}}$ & $55.48 \pm 6.98^{\mathrm{b}}$ & $6.96 \pm 1.59$ & $48.43 \pm 5.14^{\mathrm{c}}$ \\
\hline
\end{tabular}

*See Table $2 .{ }^{\mathrm{a}-\mathrm{c}} \mathrm{Mean} \pm \mathrm{SD}$ with different superscript within columns is differ significantly $(\mathrm{P}<0.05)$.

\section{Morphometrical Head Sperm after Separated}

Morphometric evaluation of sperm head after separation and proportion of $\mathrm{X}$ and $\mathrm{Y}$ sperm for each treatment can be seen on Tables 4, 5 and 6. Result of this study showed the morphometric sperm head area in the $\mathrm{X}$ fraction control and channalbumin with range $36.82-39.02 \mu \mathrm{m}^{2}$ greater than all treatment in the $\mathrm{Y}$ fraction with range of head area 34.87-36.54 $\mu \mathrm{m}^{2}$ (Tables 4 and 5).

There is no information yet on morphometric sperm of SO bulls. Based on our data SO bulls have head area sperm 34.87-39.02 $\mu \mathrm{m}^{2}$ with perimeter of 23.82-25.03 $\mu \mathrm{m}$, length 8.61-9.36 $\mu \mathrm{m}$ and and width $4.58-5.04 \mu \mathrm{m}$. This is in line with previous research that Brahman cattle (Bos indicus) has average sperm head area of $39.97 \pm$ $0.17 \mu \mathrm{m}^{2}$ with length of $9.43 \pm 0.02 \mu \mathrm{m}$ and width of $5.13 \pm 0.01 \mu \mathrm{m}$ (Rubio-Guillen et al., 2007). However according to Garner (2006), the morphometric of male (Y) sperm head after separation with flow-cytometric had average 34.5 $\mu \mathrm{m}^{2}$, sperm head length $9.1 \mu \mathrm{m}$ and width of
$4.7 \mu \mathrm{m}$ with percentage difference of DNA content $\mathrm{X}$ and $\mathrm{Y}$ was $3.8 \%$.

Futher research in Fresian Holstein (Situmorang, 2013) reported that morphometric head of sperm separated using egg white albumen columns in the top fraction (X) head area was $35.7 \mu \mathrm{m}^{2}$ with length was $8.7 \mu \mathrm{m}$ and width was $4.7 \mu \mathrm{m}$ was greater compared to the bottom fraction (Y) which head area was $33.7 \mu \mathrm{m}^{2}$, length was $8.4 \mu \mathrm{m}$ and width was $4.6 \mu \mathrm{m}$, with the percentage of female offspring is $65 \%$ and the best incubation time was 20 minutes.

Separation of sperm with channalbumin column is flexible and easy to be applied, for sperm separation based on the characteristic differences of sperm $\mathrm{X}$ and $\mathrm{Y}$ such as motility, morphology and size of head sperm. Moreover Beernink (1993) reported that albumin column separation resulted sperm bearing $\mathrm{Y}$ chromosome move more quickly than the $\mathrm{X}$ chromosome and $\mathrm{Y}$ bearing sperm improved swimming ability after isolated via an albumin column. 
Table 4. Morphometric of Sperm Head in the Top Fraction (X) after Separation

\begin{tabular}{ccccc}
\hline \multirow{2}{*}{$\begin{array}{c}\text { Top Fraction* } \\
(\mathrm{X})\end{array}$} & Area $\left(\mu \mathrm{m}^{2}\right)$ & Perimeter $(\mu \mathrm{m})$ & Length $(\mu \mathrm{m})$ & Width $(\mu \mathrm{m})$ \\
\cline { 2 - 5 } & $39.02 \pm 3.61$ & $25.03 \pm 1.0$ & $9.36 \pm 0.58^{\mathrm{a}}$ & $4.99 \pm 0.40^{\mathrm{a}}$ \\
P0x & $36.82 \pm 2.89$ & $24.49 \pm 0.91$ & $8.82 \pm 0.49^{\mathrm{b}}$ & $4.66 \pm 0.35^{\mathrm{b}}$ \\
P1x & $37.77 \pm 3.17$ & $24.73 \pm 0.78$ & $9.02 \pm 0.53^{\mathrm{ab}}$ & $5.04 \pm 0.39^{\mathrm{a}}$ \\
P2x & $38.02 \pm 3.32$ & $24.75 \pm 0.95$ & $9.15 \pm 0.59^{\mathrm{a}}$ & $5.03 \pm 0.40^{\mathrm{a}}$ \\
\hline
\end{tabular}

*See Table 2. ${ }^{\text {a,b }}$ Mean \pm SD with different superscript within columns is differ significantly $(\mathrm{P}<0.05)$.

Table 5. Morphometric of Sperm Head in the Bottom Faction (Y) after Separation

\begin{tabular}{ccccc}
\hline \multirow{2}{*}{$\begin{array}{c}\text { Top Fraction* } \\
(\mathrm{Y})\end{array}$} & Area $\left(\mu \mathrm{m}^{2}\right)$ & Perimeter $(\mu \mathrm{m})$ & Length $(\mu \mathrm{m})$ & Width $(\mu \mathrm{m})$ \\
\cline { 2 - 5 } & $35.30 \pm 2.10$ & $24.05 \pm 1.05$ & $8.76 \pm 0.65$ & $4.61 \pm 0.42$ \\
P0y & $34.87 \pm 3.10$ & $23.82 \pm 1.06$ & $8.61 \pm 0.50$ & $4.58 \pm 0.39$ \\
P1y & $35.61 \pm 3.30$ & $24.25 \pm 0.18$ & $9.08 \pm 0.54$ & $4.79 \pm 0.43$ \\
P2y & $36.54 \pm 3.74$ & $24.26 \pm 1.48$ & $9.04 \pm 0.63$ & $4.84 \pm 0.45$ \\
P3y & &
\end{tabular}

*See Table 2.

Non-sexed sperm had the proportion of $\mathrm{X}: \mathrm{Y}$ sperm $(54.18 \%: 45.82 \%)$ while the proportion of predicted $\mathrm{X}: \mathrm{Y}$ in channalbumin treatment was $62.77 \%: 79.13 \%$ compared to the control (BSA) was $69.00 \%: 76.77 \%$ (Table 6).

Our findings in this study showed the bottom fraction of sperm had smaller area compared to the top fraction, with the proportion of $Y$ sperm was greater than $65 \%$. This result is in line with the previous study where the bottom fraction or $\mathrm{Y}$ sperm has smaller head size than $X$ sperm. Therefore, $\mathrm{Y}$ sperm are able to move faster or have higher power to penetrate the albumin separation column, whereas $\mathrm{X}$ sperm contains more chromatin in the head causing larger sperm head size (Prasad et al., 2010).

Mammalian males $\mathrm{X}$ and $\mathrm{Y}$ chromosome bearing sperm are produced in equal number by testis during mammalian spermatogenesis and involved in the fertilization process (Garner, 2008; Agca and Men, 2008). However our data non-sexed sperm of SO bulls based on morphometric head of sperm observation showed the proportion of $\mathrm{X}$ sperm was more than $\mathrm{Y}$ sperm (54.18\%:45.82\%).

The result of sex sperm separation using channalbumin, in this study resulted proportion of predicted $\mathrm{X}: \mathrm{Y}$ was $62.77 \%: 79.13 \%$ and the control (BSA) was 69.00\%:76.77\%. Meanwhile result separation using egg white albumen has proportion X sperm was $80.88 \%$ and $\mathrm{Y}$ sperm was $58.82 \%$ (Afiati, 2004), using BSA column $12.5 \%: 20 \%$ was $46.33 \%: 53.67 \%$, and BSA column 15\%:20\% was 40.50\%:59.50\% (Somarny et al., 2011). Based on this study channalbumin could separate Y sperm greater than egg white albumin separation. On the other side channalbumin superior in separating XY sperm compared to the BSA $12.5 \%: 20 \%$ and 15\%:20\% columns. It's possible that low concentration channalbumin cause low viscosity of the column which make easy for sperm movement in each fraction. However our result is still lower than flow cytometer method with resulted $90 \%$ purity ratio $\mathrm{X}: \mathrm{Y}$ sperm and minimum post thaw motilities mean 40\% (Blondin et al., 2009; 
Table 6. Proportion of Predicted Sperm Bearing X and Y Chromosome

\begin{tabular}{|c|c|c|}
\hline \multirow{2}{*}{$\begin{array}{c}\text { Fraction of } \\
\text { treatment }\end{array}$} & \multicolumn{2}{|c|}{ Proportion of sperm (\%) } \\
\hline & $\mathrm{X}$ & $\mathrm{Y}$ \\
\hline \multirow[t]{2}{*}{ Non sexed } & 54.18 & 45.82 \\
\hline & \multicolumn{2}{|c|}{ X Fraction (Top) } \\
\hline BSA $5 \%$ & 69.00 & 31.00 \\
\hline Channalbumin $2 \%$ & 42.33 & 57.67 \\
\hline Channalbumin 3\% & 55.97 & 45.03 \\
\hline \multirow[t]{2}{*}{ Channalbumin $4 \%$} & 62.77 & 37.23 \\
\hline & \multicolumn{2}{|c|}{ Y Fraction (Bottom) } \\
\hline BSA $10 \%$ & 23.23 & 76.77 \\
\hline Channalbumin 4\% & 20.87 & 79.13 \\
\hline Channalbumin 5\% & 24.27 & 75.73 \\
\hline Channalbumin $6 \%$ & 32.00 & 68.00 \\
\hline
\end{tabular}

BSA: Bovine Serum Albumin

Garner, 2006; Hamano, 2007)

Based on our result of this study, the effective concentration of channalbumin for sex separating sperm was range $2 \%-6 \%(\mathrm{w} / \mathrm{v})$. These concentrations were more lower than BSA 5\%$10 \%(\mathrm{w} / \mathrm{v}), 12.5-20 \%(\mathrm{w} / \mathrm{v})$ and white egg albumen 10\%-30\% (w/v) (Kaiin et al., 2013; Somarny et al., 2011; Afiati, 2004). This indicated that channalbumin used is more effective and economics sexing material to produce low cost frozen sexing semen. As reported by Hamano (2007) X and Y sorted sperm with low cost can increased demand of sexing semen which could increase the efficiency of meat and milk production and create a new opportunity for spreading artificial insemination technology widely.

Our further result revealed that channalbumin treatment of $4 \%: 6 \%$ is more effective for $\mathrm{X}$ bearing sperm separation (62.77\%) than other channalbumin treatment. On the other hand, channalbumin $2 \%: 4 \%$ more effective for $Y$ bearing sperm separation (79.13\%). Channalbumin $4 \%: 6 \%$ of channalbumin concentration was quite effective for sperm separation at all separation fractions with sperm proportion of $\mathrm{X}$ and $\mathrm{Y}(62.77 \%$ : $68 \%)$ which was more than $60 \%$.

\section{CONCLUSION}

It is concluded that channalbumin treatment of $4 \%$ : $6 \%$ is more effective for $\mathrm{X}$ bearing sperm separation $(62.77 \%)$ than other concentration. On the other hand, channalbumin 2\%:4\% more effective for $\mathrm{Y}$ bearing sperm separation (79.13\%). Channalbumin 4\%:6\% was effective for separation of XY sperm with higher proportion $(62.77 \%$ : 68\%).

\section{ACKNOWLEDGEMENTS}

This study was funded by Ministry of Research, Technology and Higher Education of the Republic Indonesia, contract no. 338/ M/ KPT/ 2016. Authors would like thank to Mr. Sudiro and Resky from PT. KAR Rumpin for technical help and facilities.

\section{REFERENCES}

Afiati, F. 2004. Proporsi dan karakteristik spermatozoa $\mathrm{X}$ dan $\mathrm{Y}$ hasil separasi kolom albumin. Media Peternakan. 27(1):16-20

Agca, Y and H. Men. 2008. Gender selection in mammalian semen and pre implantation embryos. In: H. Schatten \& G. M. Conctantinescu. Comparative Reproductive Biology. Blackwell Publishing, New Jersey.

Agung, P.P., S. Anwar, A.S. Wulandari, A. Sudiro, S. Said and B. Tappa. 2015. The potency of sumba ongole (so) cattle: a study of genetic characterization and carcass productivity. J. Indonesian Trop. Anim. Agric 40 (2):71-78.

Axl, R.L., M. Dally, B.A. Didion, R.W. Lenz, C.C. Love, D.D. Varner, B. Hafez and M.E. Bellin. 2000. Semen Evaluation. In: B. Hafez \& E.S.E. Hafez (eds.) Reproduction in Farm Animal. $7^{\text {th }}$ ed. Lippincott \& Wilkins, Philadhelpia.

Beernink, M.D., W.P. Dmowski and R.J. Ericsson. 1993. Sex pre selection through albumin separation of sperm. Fertil. Steril. 59(2): 382-386

Blondin, P., M. Beaulieu, V. Fournier, N. Morin, L. Crawford, P. Madan and W.A. King. 2009. Analysis of bovine sexed sperm for IVF from sorting to the embryo. Theriogenology 71:30-38.

Burroughs, C.A., J.K. Garaham, R.W. Lenz and G.E. Seidel Jr. 2013. Seminal plasma effects on sex sorting bovine sperm. Theriogenology 79:551-557. 
Chasanah, E., M. Nurilmala, A.R. Purnamasari and D. Fithriani. 2015. Chemical Composition, Albumin Content and Bioactivity of Crude Protein Extract of Native and Cultured Channa striata. JPB Kelautan dan Perikanan 10 (2 ):123-132

Garner, D.L. 2006. Flowcytometric sexing of mamalia sperm. Theriogenology. 65:943957.

Garner, D.L and G.E. Seidel Jr. 2008. History of commercializing sexed semen for cattle. Theriogenology. 69:886-895.

Gunawan, M., E.M. Kaiin and R. Ridwan. 2017. Increasing Bali cattle productivity with sexed sperm artificial insemination in Techno Park Banyumulek, West Nusa Tenggara. Pros Sem Nas Mas Biodiv Indon. 3(2):216-219.

Hamano, K. 2007. Sex pre selection in bovine by separation $\mathrm{X}$ and $\mathrm{Y}$ chromosome bearing spermatozoa. J. Reprod. Dev. 53(1):27-38.

IAEA. 2005. Improving artificial breeding of cattle and buffalo in asia guidelines and recommendations. IAEA. Vienna. Austria : 12-14

Kaiin, E.M., M. Gunawan and F. Afiati. 2013. Production of frozen sexing sperm separated with BSA coloumn method with standardization on artificial insemination center. International Conference on Biotechnology, Bogor. p. 67-72.

Kavac, A., N. Lundeheim, M. Aidnik and S. Einarsson. 2004. Sperm morphology in Estonian and Tori Breed Stallions. Acta Vet. Scand. 45:11-18.

Mahaputra, L., M. Mafruchati, N. Triakoso and R.D Aries. 2012. Separation of bearing $x$ and $y$ chromosome limosin bull spermatozoa by using percoll and chicken eggs albumen. J. Biopasca. 14(3):172-175.

Moura, A.A., D.A. Chapman, H. Koc and G.J. Killian. 2007. A comprehensive proteomic analysis of the accessory sex gland fluid from mature Holstein bulls. Anim. Reprod. Sci. 98:169-180.

Mustafa, A. M., W. Aris and K. Yohanes. 2012.
Albumin and zinc content of snakehead fish (Channa striata) extract and its role in health. Int. J. Sci. Tech. 1(2):1-8

Nugroho, M. 2013. Isolasi albumin dan karakteristik berat molekul hasil ekstraksi secara pengukusan ikan gabus (Ophiochephalus striatus). Int. J. Food. Sci. Tech. 9(1):40-48.

Paddrik, P., T. Hallap, T. Kaart, T. Bulitko and U. Jaakmal. 2012. Relationships between the results of hypo-osmotic swelling tests, sperm motility, and fertility in Estonian Holstein dairy bulls. Czech. J. Anim. Sci. 57 (10):490-497.

Prasad, S., S. Rangasamy and S. Satheshkumar. 2010. Sex pre selectionin domestic animals current status and future prospects. Vet. World 3(7):346-348.

Romadhoni, A.R., E. Afrianto, R.I. Pratama and R. Grandiosa. 2015. Extraction of snakehead fish [Ophiocephalus striatus (Bloch, 1793)] into fish protein concentrate as albumin source using various solvent. J. Aq.Pro. 7:4-11.

Rubio-Guillen, J.L., J.J.G Lopez Brea, M.C. Estesso, M.R. Fernandez-Santos and D.M.G. Villalobos. 2007. Head dimensions of brahman and their crossbred bull spermatozoa are affected by cryopreservation. Revista Cientifica XVII(5): 508-513.

Sharma, M. and N. Sharma. 2016. Sperm sexing in animals. Adv. Anim. Vet. Sci. 4(10):543549.

Situmorang, P., R.G. Sianturi, D.A. Kusumaningrum and Maidaswar. 2013. Female calves born resulted from an artificial inseminatioan (AI) using sexed sperm separated with egg albumin coloum. J. Anim. Vet. Sci. 18(3):185-191.

Somarny, W.W.M.Z., Y.J Tan, S. Mat-Tasol, Y. Jasmi, K. Musaddin and J.A. Johari. 2011. Separation of Y-chromosome bearing bull's spermatozoa using an albumin gradient technique. Malaysian. J. Anim. Sci. 14:1319 